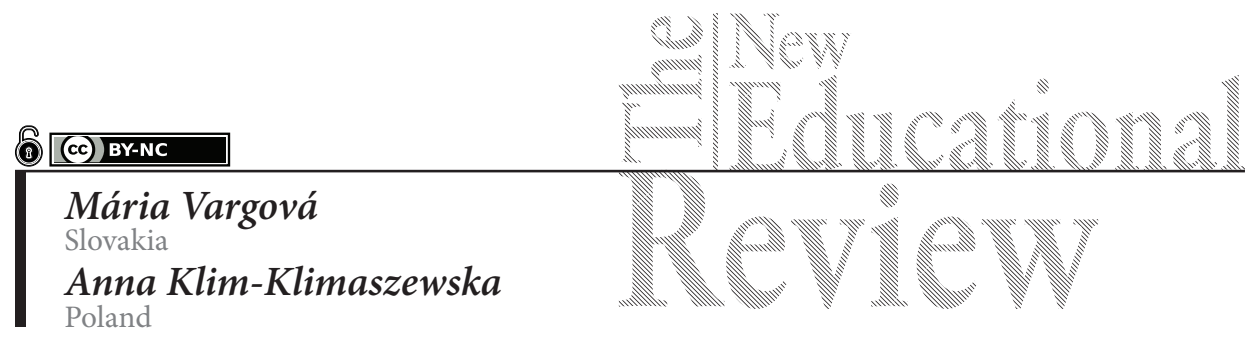

\title{
Through the Diversity of Children's Game to the Subsequent Learning
}

DOI: 10.15804/tner.2021.65.3.13

\begin{abstract}
Children's game makes a part of children's lives. The paper provides partial results of empirical research focused on children's game in the home and school environment. The character of the empirical research was diagnostic and quantitative. The subject of the research was children's game and its implementation for children under 12 years of age. There were 218 individual respondents from all over Slovakia who participated in the individual interviews. They gave oral answer to questions about the game in their childhood and the way it way realized. Here we also present the approach of teachers and psychologists. Due to political-pedagogical character, we divided the game and the respondents into three categories according to the age and childhood.
\end{abstract}

Keywords: Children's game, children, learning, preschool age, school environment

\section{Introduction}

The game is a specific activity of a human being. It is a part of history, and, at the same time, a reflection of society. It is an integral part of the children's world. We are familiar with many different theories on the meaning of games in the area of philosophy, psychology, pedagogy and sociology (e.g., Plutarch, Quintilianus, Comenius, Fröbel, Montessori, Elkonin, etc.).

In 1938, the Dutch professor J. Huizinga (1872-1945) published the book "Homo ludens" (Man the Player), in which he tried to characterize the game as a primary formative element of human culture (Huizinga, 2016). According to the 
German philosopher E. Fink (1905-1975), the game has an intrinsic dimension; the individual internal dimension belongs to man and to all his activities - by definition he determines serious and unserious human actions (Fink, 1960). The French sociologist and anthropologist R. Caillois (1913-1978) in his book „Games and People" (Caillois, 1958) proceeds from Huizing, but also E. Fink, and adds the uncertainty of the outcome of the game. His starting point for the division is what prevails in a particular game (competition, chance, behavior ,as if” or dizziness, etc.). He tries to explain the phenomenon of the game at the semantic, social and anthropological level.

This is also confirmed by B. Sutton-Smith (1924-2015). Instead of deriving exactly what the game is, he draws from the diversity of its functions (1997). J. Piaget (1896-1980) states the interval from the birth of a child to about 11-12 years of age. It covers three periods: sensorimotoric (up to almost 2 years of age), symbolic or egocentric representations $(2-7,8$, divided phases $2-4,5-7,8)$ and operational $(7,8-11,12)(1951)$.

At present, we can consider the game to be one of the proven methods of the education process in preprimary and primary education. The child learns through game instinctively and naturally. We know that learning styles are also related to different types of intelligence. H. Gardner (1943-) along with his colleagues identified several types of intelligences based on which an individual can be educated. Gardner's theory states that every child has all kinds of intelligence (linguistic intelligence; logical-mathematical intelligence; spatial intelligence; musical intelligence; bodily-kinesthetic intelligence; naturalistic intelligence; interpersonal intelligence; and intrapersonal intelligence), however, some (2 to 3) are predominant, which means that the child uses them more often. Discovering the child's preferred type of intelligence and learning style can help us when planning and creating a learning strategy in games.

Children are naturally curious from birth and are interested in various thematic areas. It has to do with the education and social environment. Again, we see a mirror in the game. In order for the child to learn during the game, and, at the same time, for a game to be fulfilling, the child needs to have his needs fulfilled. We were introduced to them by A.H. Maslow (1908-1970) and the hierarchy of needs he presented.

One of the needs of a child is his or her personal well-being. It can be generally described as a long-term emotional state in which a person shows satisfaction with his or her life. Well-being indicates a state in which a person is well. Other things that are also related to it, but are not synonymous, are: satisfaction and mainly life satisfaction, then welfare, pleasure, prosperity and happiness. It is therefore 
a long-term state - that lasts from days to weeks, which can be influenced by actual living or actual experiences and mood. It is characterized by stability over time and consistency in various situations. (Kebza, Šolcová, 2003). We can observe this well-being during children's games from two perspectives - subjective well-being and psychological well-being. These two perspectives complement each other also when children play games.

\section{Research Focus}

Children's game often fascinates not only a child, but also his parents and teachers. In today's world full of media, we can see a change in children's games with a focus, approach and social dimension. The game as a fundamental activity of a child contributes to the formation of the child's personality, his or her approach and the way of learning. Not only a parent should pay attention to the game of his or her children, but also a teacher in the school environment and beyond. To know how to play the game should not be taken for granted. While playing the game, a child cultivates his or her soft motoric skills, a sense of order, progression, patience, aesthetics, creativity, how to complete the activity, etc.

In Slovakia, we meet several experts in children's game who have done a lot of research and created collections of games for children. One of the most wellknown experts is K. Ondrejka (1929-2011); his collection of children's folk games is truly admirable (we present a selection from 1980, 1992). Even in the today's education process we still observe that children find games of our grandparents interesting. Many times, they learn something new, something that is gradually being forgotten, e.g., imitation of washing the clothes in a stream, etc. This is also confirmed by M. Uhrinová (2015). Her theory is based on the connection that children's folk game is suitable for developing a feeling for beauty, harmony and cultural heritage.

Today's children are interested in computer games, which is also observed by research that are currently being carried out (Juszczyk, 2004, Karasová, 2019).

In the education process in preprimary and primary education, we distinguish several didactic strategies (Vargová, 2013, Vargová, Kostelanský, 2016). At present, we find the game integrated in the education process. The focus of education has undergone several changes. From learning as much as possible to acquiring the essence of education - who we teach and why.

In the theory and practice, we encounter the implementation of children's game in the education process (Klim-Klimaszewska, 2018). In both preprimary and primary education, psychologists now agree that the more the game is controlled, the more the child is restricted and his or her creativity is hampered. 


\section{Methodology of Research}

\section{General Background of Research}

The empirical research had the diagnostic and qualitative character. It was conducted from 2019 to 2021 and we addressed various age categories. The subject of the research was children's game and its implementation in children from 3 to 12 years of age. The respondents we addressed were from different age groups coming from each region in Slovakia. We inquired men and women born between the year 1921 and 2018. We compared the statements from childhood with the statements of teachers and school psychologists.

The cognitive goals of the research included the following objectives:

- to ascertain the implementation of children's game by the year 1950, from age 3 to age 12,

- to ascertain the implementation of children's game from the year 1950 to 2000, from age 3 to age 12,

- to ascertain the implementation of children's game from the year 2000 to the present, from age 3 to age 12,

- to analyze the educator's perspective on children's game and its application in the education nprocess in preprimary and primary education,

- to analyse the school psychologist's perspective of children's game and its application in the education process in preprimary and primary education.

Our research was based on the following questions:

RQ1: What is the children's interest in different types of children's games?

RQ2: Does the year of birth influence the relation of a child to various types of games?

RQ3: Are children's games part of education in preprimary and primary education, regardless the year of study?

RQ4: How do children's games affect the development of a child's personality?

\section{Sample of Research}

The research involved 218 respondents from different age groups. The oldest interviewee was born in 1921 and the youngest was born in 2018. When selecting the respondents, we took into consideration the municipality (town/city/rural) and the region in which they grew up. During the interviews, the responses of the respondents were audio-recorded (with the respondent's consent) and notes were taken. 
Among the participants of the research were teachers who started teaching before the year 1950 up to 2000 and have been teaching up to now. We chose the responses of the three teachers with at least thirty years of experience. Two of the teachers have been teaching till today. The other respondents included three school psychologists who have more than 5 years of independent experience. ${ }^{1}$

\section{Instrument and Procedures}

In the research, we used the interview as our primary method. Also, we used the method of diagnostic observation and transcription of recordings. The interview was structured, i.e. we used the same questions in the same unchanged order. The participants, especially those from the older age group, instinctively followed up the subsequent questions in a smooth sequence without seeing them beforehand. The interviewer was an educator qualified to work with children in preschool and school settings.

\section{Data Analysis}

The qualitative assessment was based on the conducted interviews, observation of today's children, transcription of recordings, analysis of historical letters and collections of games. We divided the respondents into three categories, which are more or less landmarks not only in terms of politics but also in terms of pedagogy.

\section{Results of Research}

Children of preschool and younger school age who were born in the first half of the $20^{\text {th }}$ century spent more of their leisure time outdoors than indoors. Due to the economic and political conditions of the time, there was less leisure time in this period. The oldest respondent was born in 1921, i.e. we analyzed the statements from the interwar period and the period of World War II. The respondents answered coincidently that these years were difficult and they had very little time to play games. Children in the countryside used to help on the farm, in the field and also looked after other siblings. The respondents mentioned the songs they used to sing and simple movement games that could be played while working in the fields, e.g. Oli, oli Janko; Golden Gate; O chain, o chain, etc. The most frequent response was that they had a simple toy to play with. In several statements the

\footnotetext{
1 Statistics indicate that there are about 500 school psychologists in Slovakia at present, however, not all of them work in schools. Some of them work also in counselling centres.
} 
respondents stated it was a stick with a string that a child pulled behind, rippling the water. Another game they mentioned was that the children were standing in a circle with one child in the middle. The child that was in the middle of the circle went around with the string and the other children jumped up so as not to touch the string.

At that time, games were clearly divided into girls' and boys' games. Girls used to play with dolls that were crafted of cloth, wood or cornhusk. Dolls made of cloth were the most frequently mentioned in the responses. One respondent said she had toys from abroad as her father was a trader. Boys used to play mostly as soldiers and partisans. Chasing, hiding, climbing the trees, jumping into the hay - these activities were mentioned both by girls and boys. One of the interesting things was the home-made ball made from materials that were available. Rubber from old rubber bands, old joined cloth and old canvas were the most frequently mentioned materials.

There were no games played during the education process in the school environment. The games were played only during breaks. The education process was focused only on memorization and discipline. However, the situation was different in preschool institutions, which were called children's nursery in our area (or kindergarden abroad). Here, children used to learn through game, song, dance and handicrafts.

A teacher (1930-2021) who began her teaching career in those years (before the year 1950) mentioned notebooks and taking notes. She used to seek the games herself. Literature was scarce and even when there was some, it was not available. We can see from various periodicals from the 1930s (e.g. Our School, etc.) that articles and the latest findings from around the world were translated. Also in our area, the experts were beginning to take an interest in the expertise in the education process. However, due to the political situation in our country and in the world in the first half of the $20^{\text {th }}$ century, we can see great differences in schools. The system was built upon traditions and the Czech literature that was also available in Slovakia.

In terms of legislation and pedagogical reality, the education process in Slovakia was also marked by Hungarian influence in the former Czechoslovakia. The school law of the Austro-Hungarian period was in force in Slovakia until 1948.

There is a large span from 1950 to 2000 , and, with regard to our survey, it is also the longest. In the 1950's and 1960's we can see childred playing spontaneous games with the dominance of the movement games. There are also games connected with singing: music and movement games that have been preserved from the previous generation. The games are also enriched with new elements that are 
related to the advent of the new political regime. In the movement games, we can see the representation of ball games, jump rope games and Chinese jump rope games. In the research, there were the repeated activities that mentioned playingball games during breaks, i.e. ,ball nursery' - children from one to ten had to do some action with the ball, e.g. to throw the ball against the wall once, to bounce the ball off the ground twice, to bounce the ball against the wall three times, clapping once between each bounce, etc. The rules were varied according to the number of children. Another interesting game was the so-called "hopscotch” - children drew numbers from one to nine on the ground, which were in squares in a row for jumping on one leg or on two legs. Some used pebbles to jump in sequence, others used a piece of glass or chalk, which they used for drawing. Nowadays, there are different variations of this game in kindergartens and primary schools in the corridors and also outside on the pavements. The „hopscotch” was also done with a jump rope. The difficulty started with number ten, which was the easiest jump, up to number one, which was the hardest jump, so called egg.

A kindergarten teacher states that the children's favourite games were shopping and selling. She used variations for different topics.

Again, there are different examples of games, game strategies, and learning itself in the periodical called Preschool Education (Predškolská výchova), which started to be published in the 1940s (and has been published since then).

The 1970s are the intersection between the first two decades and the following decades. We don't see much difference in the 1970s and 1980s. Children again favoured outdoor games. New movement games were added for the observation. In various sung or spoken accompaniments we hear expressions from the world languages, or tongue-twisters that resemble a foreign language. Other games included games with strings. These games required at least two children to play. One child would make the shape of a string and hold it on his or her fingers. Then, another child would skillfully intertwine the string and the pattern would appear in his or her hands. The game continued until one of the children made a mistake.

These games were played until the 1980s. At this time, writing and logic games came into use, especially with children in primary education. They started to play tanks, boats, but also the familiar game called „name, city animal, thing“. As if these games have become supplementation of free time activties during breaks, or substitute - free lessons. The children's home games also gradually started to move indoors.

Of the outdoor games, tag games, hide-and-seek, dodgeball but also games with more rules, e.g. Sugar; Coffee; Lemonade; Tea; Rum; Boom or Statues, Statues, Change! were still much popular among childen. 
In the 1990s, we observe the change in games as well. Classical games started to be on a decline and children are more engaged in simple fill-in-the-blank games via computers and consoles. We saw some indications of it already at the end of the previous decade, with the popular console in which a wolf was catching eggs off the shelves into a basket so they wouldn't fall and break. With the opening of the frontiers, new toys started to come in and a new type of games were adapted with children by means of new technologies.

However, the teachers stated that at the end of the century, there was still the interest in movement and creativity. In that period, children were also seeking new rules for their games.

From the year 2000 to the present, we observe the differences in comparison to previous statements. We take into account that in this case we interviewed children and adolescents. We also can see the differences in the statements concerning the contemporary game with the contemporary trends and focuses. The biggest phenomenon of this time, and the fact that is confirmed by educators and psychologists, is that children have a difficulty with concentration and with paying long-term attention to their tasks.

In kindergartens, the children are also taught traditional games, and, at the same time, they are focused on didactic play through which they can learn. In primary schools, it is already common for a game to be part of not only the breaks but also the lessons. Through play, children are exposed to new knowledge in a non-violent way.

Taking into accout the psychologists' perspective, we observe the following levels:

1. Why is game important for a child? The game is the fundamental and the most natural activity of a child, and it helps him or her to navigate in the social environment and become familiar with new situations, thus the child is being prepared to manage them successfully. Through game, the child discovers the world, communicates, and learns. The game in preschool age is the first factor in the development of social contacts, in which predominate social games with peers. A child spends most of the time of the day playing games. A child develops his or her abilities, skills that he or she needs for collective games with other children. The themes of games are also alternated and the cooperation among particular group members is not long. However, its role is very important. Here the child forms contacts with friends through which he or she learns to assert himself or herself in the group, enters into dialogues, learns to work in a team, and, at the same time, vents stress, tension and learns to resolve potential conflicts. The game in preschool age becomes a preparation for doing his or her duties and homework. 
At younger school age, the content and form of game are being changed. At this age, we no longer talk about functional and manipulative plays, but rather about movement games, which are of a group character and are very important for appropriate mental, physical and motor development of a child. Last but not least, the game has an irreplaceable place in the formation of the child's personality.

2. Why is it good to apply the game during the education process? We use game in preschool age in the education process as a game in which there is a need to construct something - games in this sense are directed towards the creation of a certain product. Then, we also talk about role (theme) games, in which children portray the characters from various children's stories. And finally, the last game is focused on the need for competition and cooperation, in which we develop the ability to win, but also to accept and process the losses that form an integral part of life.

At younger school age, games are a very effective method, an educational tool, a form and a condition for learning and the development of the child's personality. The game tends to be a means of relaxation and work and a source of knowledge and experience for children of younger school age. Didactic game plays an important role in the education process. It is a very effective means of acquiring new skills or knowledge. The game properly compensates the intensity of teaching process and has a relaxing effect. It is a very beneficial form of non-violent formation and can be very helpful in the education process.

The benefits of games are: spontaneity of children, motivation, modelling of life experiences and usefulness in everyday life.

3. What are the benefits of playing the game for a child? The game is an innate activity of healthy development. Through play, a child learns to cope more easily with stress. Children play for pleasure, relaxation; they practice body movements, delve into the imagination by making up their own stories. In every child's room, we should find plush toys, dolls, animals, doll figures and creative material. Children need to play freely when they are on their own and should lead the game themselves. The game has a positive effect on brain development, mental, physical, intellectual, social and emotional potential of a child. The game helps a child to build his or her own confidence; the child feels loved, happy, and safe. Also, the child develops social skills and the art of communication, visual and auditory perception, imagination and creativity, courage and perseverance, the ability to cooperate and show empathy. Thanks to games, a child learns almost everything he or she needs for life.

4. In what ways can it influence a child? Through game, a child learns and changes his or her internal conditions for carrying out other activities. Through 
game, a preschooler and younger school-age child becomes a member of the child's social group and establishes his or her own status and position. The importance of children's game also lies in the fact that a preschooler and a younger school-age child gets to know the world primarily through games. For example, a child can learn from a loss how to cope with failure in life.

5. Game as a diagnostic tool. In diagnostics, the place of the game is irreplaceable. Observing a child at play can provide a psychologist or a teacher with valuable information. For the child, the game is a natural activity, in which he or she behaves spontaneously and can be perceived comprehensively. The game is innate and natural in children and there is something wrong if a child does not play the games. The game is an expression of his or her attitude to the world, an information of how the child perceives the reality. The game develops gradually as the child grows. Each period of development is characterized by a certain kind of game - from manipulative, through functional, role-play, thematic, to constructive game. If play does not develop, it signals to the observer that something is not as it should be.

\section{Discussion}

The results of the research show that children do not lose their interest in the game even over the decades. What changes is the focus depending on the period in which they grow up. At the beginning of the $20^{\text {th }}$ century, there were mostly movement and music and movement games. Some of the games have varied over the decades, while others are gradually being forgotten.

We cannot specify exactly whether the interest in the game is generic or individual. It depends on various factors, i.e. the social environment of a child, the financial situation, the location of the village; in the school enviroment it is a teacher and his or her perspective of the methods and the composition of children in the class. It would be interesting to address these factors further.

The child's relationship to different types of games depends on the year of birth. We can see this from the cultural and social organization of society and the hierarchy of values. The interesting thing was the fact that when there was more interest in children's game, especially in a common, spontaneous game, it was shifted to breaks in primary education. Nowadays, we incorporate it into the education process in order to engage children's attention in learning what is new and unfamiliar. In preprimary education, since the establishment of kindergardens, the game has been a part of the education process. The educators understood 
that the game is a natural part of children's life and that it fulfills the child's needs. Unfortunately, today's children need to be more induced to play games. Based on the teachers' statements we observe that the best way to engage children is when they are provided with an idea, rules and are in coordination with a teacher. Some even ask if they play the game correctly and can continue doing the same way. In traditional school system, we do not lead a child to be independent and this needs to be changed. We need to support child's spontaneity, playfulness, creativity and self-critical thinking. The game itself has a great impact on a child and the spontaneity and joy of the game should not disappear upon completing the preprimary education. In the education process, the game is one of the methods, which induces a wide range of opportunities, situations for personal development of a child, offers space for the development of cognitive skills, social and personal competencies of a child. The child discovers the world, learns to communicate and express emotions. The game influences the physical and mental development of a child.

\section{Conclusions}

The conducted research was carried out in different age categories of respondents, but it was focused on child's play from 3-12 years of age. In the interview, the respondents answered questions assigned ahead of time. Some of the respondents spontaneously elaborated their answers to the questions and recalled their childhood as the most beautiful period of their life. We took into account the fact that for some the memories were distorted, but when a particular game or game procedure was repeated regardless of respondents' familiarity, we found this to be validating. The teachers' statements were very interesting. They shared their experiences which they acquired when teaching. It was also for this reason that we chose teachers with more than twenty years of experience. Here, we noticed differences among children according to their year of birth. Also, for this reason we divided children's games and learning through game into three categories according to the year of birth. Games played by children who were born after 2000 are completely different from the games palyed by children born before the year 1950. As we have mentioned earlier, new technologies have greatly affected the way children play the games. This is confirmed by chosen psychologists. They have also identified game as a suitable diagnostic tool in the education process. In addition to interviews, it is important to carry out long-term observations to draw conclusions. 
During the education process, game should be its part. This is also confirmed by the answers of the respondents, the experience of teachers and psychologists, so that a child would develop and could live the life to the full.

\section{References}

Caillois, R. (1958). Les Jeux et les Hommes (Le Masque et le Vertige). Paris: Gallimard.

Creswell, J.D., Creswell, J.W. (2020). Research Design: Qualitative, Quantitative and Mixed Methods Approaches, $5^{\text {th }}$ Edition, Thousand Oaks: SAGE Publications Inc.

Fink, E. (1960). Spiel als Weltsymbol.(The Game as a Symbol of the World). Stuttgart: W. Kohlhammer.

Huizinga, J. (2016). Homo ludens. A Study of the Play-Element in Culture. NY: Angelico Press.

Juszczyk, S. (2004). Media influence on children and adolescents. In The New Educational Review, 2004, Vol. 2, No 3, s. 93-112.

Karasová, M. (2019). Computer games in the life of a younger school age children. In: Podejścia metodologiczne w pedagogice : koncepcje - badania - wyniki. Katowice: Wydawnictwo Uniwersytetu Ślaskiego, p. 151-160.

Kebza, V., Šolcová, I. (2003). Well-being jako psychologická a zároveň mezioborově založený pojem. (Well-being as psychological and also interdisciplinary based concept). In: Československá Psychologie, 47 (4), p. 333-345.

Klim-Klimaszewska, A. (2015). Playing as the basic form of activity of the pre-school child. In: L. Gómez Chova, A. López Martínez, I. Candel (ed.), INTED $20159^{\text {th }}$ International Technology, Education and Development Conference. Conference proceedings (Madrid, Spain, March $2^{\text {th }} 4^{\text {th }}$, 2015). Valencia: International Academy of Technology, Education and Development (IATED), p. 2068-2070.

Klim-Klimaszewska, A. (2015). The influence of play on socio-moral development of preschool children. In: L. Gómez Chova, A. López Martínez, I. Candel Torres (red.), EDULEARN15 $7^{\text {th }}$ International Conference on Education and New Learning Technologies, Barcelona (Spain) Barcelona (Spain) $6^{\text {th }}-8^{\text {th }}$ of July, 2015, Conference proceedings. Valencia: International Academy of Technology, Education and Development, p. 3717-3723. Klim-Klimaszewska, A. (2018). Educational Games and Activities in Preschool Mathematics. In: The Eurasia Proceedings of Educational \& Social Sciences (EPESS), Volume 9, Ames: International Society for Research in Education and Science (ISRES), (Iova, USA), p. 229-238.

Ondrejka, K. (1980). Podte, deti, medzi nás. Detské hry a rozprávky. (Come, Children, Among Us. Children's Games and Fairy Tales). Bratislava: Mladé letá.

Piaget, J. (1951). Play, dreams and imitation in childhood. London: Heinemann.

Sutton-Smith, B. (1997). The ambiguity of play. Cambridge. Massachusetts: Harvard University Press.

Uhrinová, M. (2015). Kulturelle Aspekte der regionalen Erziehung in den Dimensionen der 
Primarstufe. (Cultural Aspects of Regional Education in the dimensions of the primary level). Wien: Internationale Stiftung Schulung, Kunst.

Vargová, M. (2013). Námetová hra, súčast’ života dietata. (Themed game, part of child’s life). In: Odborová didaktika - interdisciplinárny dialóg 2013. Ružomberok: VERBUM, 2013. p. 159-164.

Vargová, M., Kostelanský, A. (2016). The application of a didactic game in the educational process of roma pupils. In: Dijete, igra, stvaralaštvo. Split: Filozofski fakultet u Splitu, p. 199-205. 